Article

\title{
Digital Technologies and the Public Sphere in Spain: Spatial Metaphors, Viewers' Perceptions and Demands in Light of the Democratic Challenge (2014-2017)
}

\author{
Manuel A. Broullón-Lozano ${ }^{1, *(D)}$ and María Lamuedra Graván 2,*(D) \\ 1 Departamento de Literaturas Hispánicas y Bibliografía, Universidad Complutense de Madrid, \\ 28040 Madrid, Spain \\ 2 Departamento de Periodismo I, Universidad de Sevilla, 41092 Sevilla, Spain \\ * Correspondence: mabroullon@ucm.es (M.A.B.-L.); mlamuedra@us.es (M.L.G.)
}

Received: 23 October 2020; Accepted: 26 November 2020; Published: 2 December 2020

check for updates

\begin{abstract}
During the 2010s, there was a "utopian moment" as regards the structure of media, owing to the social space created by digital culture, transmediality, and the different ways of participating in public debate. What is expected from digital information transmitted via the Web and social media is action and interaction with subjects in the public space or square. Accordingly, this paper analyses the descriptive assertions and proposals of the viewers of newscasts of Spanish television between 2014 and 2017, as regards how they perceived and represented the public space, mediatised by information through spatial metaphors. Specifically, it is based on the analysis of the transcriptions of five discussion groups and four interviews, whose aim is to examine two polarised spatial metaphors-the traffic labyrinth and the open square-and a series of demands relating to the role of journalists, media ownership, viewers' access, and the quality of democratic society.
\end{abstract}

Keywords: public service journalism; television; digital technology; reception; transmedia; democratization

\section{Introduction and State of the Question: The Digitised Space in the Face of the Demands for Democratisation}

The complex time-space coordinates in which we move form a symbolically constructed unit, a "placement" that works as our fundamental experiential spatial referent and its alteration. The knowledge and identities of subjects and communities that are established as soon as subjectivities emerge depend on both the stage setting and the geographical abstraction, which we inhabit through our use of all sorts of devices (Elwood and Leszczynski 2013). So, knowledge is inserted into a spatiotemporal structure and, therefore, formalised with a specific order, with rules, with a disposition, and consequently, with a code or, at a higher level of complexity, through a language deployed by means of discourse. As a result, discourses take shape in social practices and generate institutions and channels which also frame intersubjective life experiences, marking the times and spaces of communicative interaction (Vázquez Medel 2003) and moulding spatial settings and meanings.

In the twenty-first century, we know that this social space is traversed by all kinds of mediations, owing to the technical and hyperconnected evolution of the modern public sphere (offentlichkeit): we are living in times of a "major mediatisation" that is threatening to restrict subjective and intersubjective dynamics to a digital confinement (Pérez Tornero 2020). The social space is not only always a symbolic one, but, depending on powerful contemporary technological mediation, the public and media spheres also form, above all, a communicative space (Schlesinger 2000) subject to all kinds of 
tensions, power relationships, and frequent contradictions. In that communicative space, the public is an essential requirement, a precondition. The adjective "public", in this case, has a number of implications. Firstly, that space should necessarily be accessible to all the subjects conforming a community, thus guaranteeing a level playing field as regards their positions and interactions. Secondly, to guarantee that accessibility, there should be instruments of control, accountability, and in short, a benchmark for the functioning of placement in light of other possible configurations. In European democracies, such a function corresponds to the state, and in the particular field of the media sphere, to public media.

Those mediations are also integrated into both the material and virtual social space, whose increasingly more vague frontiers link to a unique world through devices, discourses, and symbolic practices, in the broadest senses of the word. Specifically, in the 2010s, different technological and social processes tended to coincide, displaying parallelisms. While the challenge of the digitisation of the media and daily life has suggested a paradigm of "convergence" (Jenkins 2008; Bordwell 2009; Cebrián 2004), "re-mediation" (Bolter and Grusin 2011), or "transmediality" (Gauthier 2018; Scolari 2016; Sánchez-Mesa et al. 2016), with the subsequent reconsideration of the spheres of production, circulation, and reception, in the social sphere (Alonso et al. 2016) both individuals and collectives have called for participation and empowerment in the public space (Bustamante 2008; Álvarez-Peralta 2014; Gavaldà Roca et al. 2016; Lamuedra et al. 2018).

The geomedia and geolocational processes emerging in the 2010s, such as the Arab Spring, the "indignant" and "occupy" movements, plus the Umbrella Revolution in China (Adams and Jansson 2012), have relied heavily on new information and communication technologies (hereinafter ICTs), under Industry 4.0 or the "social" turn of the World Wide Web, mobile phones, and the evolution from 3G to the very promising 5G at present and in the near future (Rodríguez-Amat and Brantner 2016). However, following that period, which could be classified as "utopian" (2012-2017), the uses to which these same digital communication tools have been put, driven by influential strategies, have set alarm bells ringing. This has resulted in the citizenry's growing mistrust of their political representatives-the "they do not represent us" that characterised the 15-M movement in Spain-their disaffection with institutions, and finally, the controversy surrounding the rise of populism and the repercussions of fake news for international political processes as important as the election that led to Donald Trump's ascension to US presidency, the Brexit referendum, and the rise of the extreme right (Vázquez Medel 2017), in what could be called a "moment of uncertainty". In this contrast between the two aforementioned historical moments ("utopian moment" and "moment of uncertainty"), the voices and demands of the previous years have not died down, but have had important consequences for our habits and for the ways in which we construct reality. In particular, their echoes can still provide some key insights into tackling the future through the convergence between technology, political debate, and activism/empowerment. All of this is represented in the perception of the public space as one that is constructed and experienced by means of spatial metaphors, such as the public square and the one-way passage.

With that in mind, there are also the parallel challenges posed by ICTs as expressive channels of storytelling - which is not only the art of telling stories, but also a device for "formatting minds", according to Christian Salmon $(2008,2011)$ - and by the citizenry's demands for participation and empowerment in light of their distrust of the functioning of the mediatised public debate.

In this context, in Europe, public information service (hereinafter PIS) has been redefined between "old technologies", namely, television in the mixed public/private system, and "new technologies" relating to the Internet, which have opened up a vast range of disruptive possibilities as regards the former. Such transformations have given rise to an ever-shifting scenario in which current issues of utmost importance, such as the validity of PIS itself, the legitimacy of "the public" versus "the private", the social organisation of labour (García de Madariaga 2014; Imbert 2008), and even the journalistic profession per se (Media Intelligence Service 2017; García de Madariaga et al. 2016), are being addressed. In view of this, there is presently tension between digitisation, the diversification 
of offerings, the appearance of new platforms, the shaping of interfaces in the "new media", and lastly, the modification of the reciprocal image that senders and receivers maintain.

In the Spanish case (AIMC 2012), priority has been given to PIS (European Commission-Directorate General Communication 2016, 2018; Media Intelligence Service 2018) as a fundamental agent of the democratic system, whether this be down to tradition from a historical point of view or to the demands that the citizenry and academia have been expressing since the advent of the Internet as the main arena in which all the agents participating in the public sphere vie. So, at the end of the decade, it was already possible to perceive a new way of experiencing that space as regards the metaphors representing it, the agents occupying it, and the ways of circulating in it.

The study methodology employed is described below, followed by the results, discussion, and conclusions.

\section{Methodology}

\subsection{Research Hypothesis and Questions}

The research hypothesis is grounded in the relevance that the type of spatial metaphors, with which the communicative space is conceptualised, through the agents, devices, and technological mediations intervening in the digital public space, has for the quality of democracy. Furthermore, its objective is to describe them in the immediate wake of the utopian moment taking place in the period from 2011 to 2014. This is a specific line of research of a broader project ${ }^{1}$ which studied citizens' and news producers' discourses on public service media. Obviously, the spatial metaphors that generate subjectivities and intersubjectivities are not static ideas. The data allow for observing a symbolic struggle between several mental representations that different groups shape through their communicative uses and practices. In light of the forgoing, the following research questions have been formulated:

1. What are the perceptions of the subjects inhabiting the "place", and the type of placements that their interactions generate?

2. What kind of demands are the subjects, whether they be users or agents with the ability to intervene, making vis-à-vis future "places" through the use of technologies that modify the linearity of information flows?

3. What role can PIS play, exercising social leadership, in light of the perceptions and challenges arising in the digitised public place?

This paper describes a topology of the perception of the communicative space during the utopian period from 2014 to 2018, by directly enquiring into the discourses of media users in Spain. It documents practices, uses, and projections and examines how spatial metaphors are shaped.

\subsection{Empirical Sources: Enquiries and Materials}

In order to identify, analyse, and understand both the perceptions and demands of viewers of Spanish public service television, their discourses were examined during the period between 2014 and 2017, when the "utopian moment" was brought to a close. The samples making up the corpus of this research project were gathered from semi-structured discussion groups (see Table 1) with ideologically likeminded subjects, in addition to customised interviews in specific cases deserving further inquiry (see Table 2), with the aim of identifying shared discourses emerging during the discussions.

1 This paper forms part of the "Dinámicas de relación ante el cambio social: contextos, contenidos, productores, público y produsuarios en las noticias de TVE e YLE" (CSO2013-45470-R) research project, financed by the Spanish Ministry of Economy and Competitiveness' 2013 National Programme for Research Aimed at the Challenges of Society, and led by María Lamuedra and Manuel Ángel Vázquez Medel. This programme also received supporting funds from the European Regional Development Fund (ERDF). 
Table 1. Discussion groups in the project 2014-2017.

\begin{tabular}{cccccc}
\hline & Activists & Technophiles & Public Sector Workers & Conservatives & Without Higher Education \\
\hline City & Seville & La Laguna & Madrid & Seville & Seville \\
\hline Date & 6/03/2015 & $17 / 03 / 2015$ & $27 / 04 / 2015$ & $29 / 05 / 2015$ & $14 / 07 / 2016$ \\
\hline Moderator & C. Mateos & C. Mateos & M. Lamuedra & M. Lamuedra & M. Broullón \\
\hline Code & A & T & PSW & C & WHE \\
\hline
\end{tabular}

Table 2. In-depth interviews in the project 2014-2017.

\begin{tabular}{ccccc}
\hline & $\begin{array}{c}\text { Rural Profile with Higher } \\
\text { Education (Retired) }\end{array}$ & $\begin{array}{c}\text { Rural Profile without Higher } \\
\text { Education (Working) }\end{array}$ & $\begin{array}{c}\text { Peripheral Urban Profile } \\
\text { (with Higher Education) }\end{array}$ & $\begin{array}{c}\text { Peripheral Urban Profile } \\
\text { (without Higher Education) }\end{array}$ \\
\hline Place & Ubrique (Cadiz) & Ubrique (Cadiz) & $\begin{array}{c}\text { La Línea de la } \\
\text { Concepción (Cadiz) }\end{array}$ & $\begin{array}{c}\text { La Línea de la } \\
\text { Concepción (Cadiz) }\end{array}$ \\
\hline Date & $6 / 03 / 2015$ & $17 / 03 / 2015$ & $27 / 04 / 2015$ & $29 / 05 / 2015$ \\
\hline Interviewer & M. Broullón & M. Broullón & A. Torres & A. Torres \\
\hline Code & INI-S1 & INI-S2 & INI-S3 & INI-S4 \\
\hline
\end{tabular}

During the first phase of the research, an intentional sample was gathered by selecting profiles whose discourses were likely to have been influenced by the spirit of the utopian moment. Three groups were formed: (1) people linked to citizen movements and emerging and active political actors; (2) people linked to the executive apparatus of public service in the field of cultural reproduction-excluding public television; and (3) a group of people who mainly resorted to digital news and participatory media websites.

An initial analysis of these three groups showed that they shared similar critical diagnoses and demands (see Lamuedra et al. 2018; Lamuedra Graván et al. 2020). In view of this, an attempt was made to determine whether or not these-and other-similarities in their discourses could be found in other social groups. This relative homogeneity may be explained by a certain discursive hegemony in the political context at the time (Conde 2009, p. 139) and/or because the respondents were inadvertently mainly left-wing voters. In order to delve deeper into this issue and guarantee a certain degree of ideological pluralism, (4) a group of conservative voters was created. Furthermore, it was also observed that most of the subjects in the first four groups held a university degree, whereby a group in which this variable was not present was formed of (5) people without higher education.

Henceforth, the subjects participating in the discussion groups will be referred to using the following codes: "Without higher education" (WHE), "Public sector workers" (PSW), "Conservatives" (C), "Activists" (A), and "Technophiles" (T), followed by the letter S and the subject's number (e.g., WHE-S1 and T-S5). As for the in-depth interviews, the interviewees will be identified with the generic label IDI-S + number (e.g., IDI-S1 and IDI-S4). Furthermore, a reasonable degree of general diversity was required to ensure that different positions were taken into account. Thirty subjects took part in the discussion groups: 18 men and 12 women. Five of them were aged over 55, 12 between 36 and 55, and 21 under 35. All the groups, which were created in different provinces-Madrid (1), Seville (3), and La Laguna (1) - had from six to eight members, according to the approach recommended by Javier Callejo-Gallego (2002, p. 418).

2.3. Interpretation of the Empirical Samples. Spatial Metaphors: Intersubjective Visions from the Perspective of the Placement/Displacement Theory (P/DT)

These empirical samples were interpreted by applying the discourse analysis method, as befits an ultimately linguistic corpus (Lozano et al. 1982). From the different symbolic dimensions recommended by discourse analysis, in this study, spatial isotopy was chosen, insofar as it results from the perception of relationships, mediations, visual and interactive technologies, and the projection of experiences.

The spatial dimension is an inalienable part of human experience and conscience. In transit and movement, the subject is constructed, subjectivities are opposed through the experience of otherness, 
and in terms of displacements, representations of the world emerge: cartographies, maps, geographies, and cosmologies. In contemporaneity, the awareness of the world circulates in virtual spaces, no less experienced than their physical counterparts, in whose more or less abstract territories subjects continuously move, establishing relationships and elaborating symbolic and cognitive models of worlds in order to be able to plot future courses.

In this vein, the placement/displacement theory (P/DT) (Vázquez Medel 2003, pp. 21-34) offers both a conceptualisation of space and a dynamic analytical model of the process with which meaning is narratively shaped. That space is defined as "place-ment": here and now, "material placement, a consequence of our res extensa, of the corporeity comprising us, but also a symbolic placement, woven into/by the networks of the res cogitans, our mind" (Vázquez Medel 2003, pp. 26-27). So, the "place" is a representation, a model of reality, a product of confronting subjectivities, which in a dynamic fashion, ends up shaping spatial metaphors. Subjects "place" and "displace" themselves using coordinates that involve patterns and codes, plus possible dynamics of change. Assuming that any ecosystem can propose-and question - its placement and displacement models, the intention here is to explain the subjectivities revolving around the media/information ecosystem from this perspective, enquiring into the spatial metaphors in which subjects place and displace themselves to construct and represent themselves.

The results will be presented in the following sections. The subjects' perceptions-descriptive assertions-and demands-purposive assertions-were isolated according to the thematic areas appearing in the transcriptions of the group discussions, without neglecting the linguistic and pragmatic discourse markers.

\section{Results}

\subsection{Descriptive Assertions: Spatial Metaphors}

\subsubsection{The Placement of the Digital Public Sphere: The Encyclopaedia or Network}

If there was a consensus among the subjects, then that was above all their very positive assessment of ICTs. They were identified with all the euphoric values of progress, innovation, education, and individual freedom, perceived as the freedom of movement in the public place. The most "integrated" - in the words of Umberto Eco (2013)—regarded them as a new communication and social paradigm, especially the members of the "conservative" and "technophile" groups, the latter being the most "integrated" of all:

As soon as you type in a word, it [the Internet] offers you thousands of options. There [on the Internet], there're many ways of participating, working, everything. For me, it's like a huge encyclopaedia. (T-S1)

This encyclopaedia containing all that could be said, known, and thought was conceived as something utopian and accessible. Furthermore, the process of "convergence" (Jenkins 2008) or "re-mediation" (Bolter and Grusin 2011) clearly appeared, for which reason the Internet included and re-orientated all previous forms of communication: "I aspire to find on the Internet a substitute for all the other media. That is, on the Internet I have access to TV programmes, radio programmes, online newspapers ... . I have it all on the Internet" (T-S6). This was a bad omen for the "old media", particularly for PIS: "TV model, big and for the whole country, a ... [ . . . ]. I hardly watch it any longer. Everything I watch I watch on the Internet" (A-S3).

This view coincided with that of the rural users: working women over 60 and willing to participate in the digital public space. For them, ICTs gave them access to a universe of possibilities of which their personal pathways had not allowed them to take advantage until then. Thus, the democratisation of information was associated with its free availability, a fully "integrated" reasoning: "That I can press a key and ask my friend Google or Wikipedia ... " (PSW-S2). 
Judging by their discourses, the subjects were interested in discovering what those technologies were and how they worked. In other words, there was a displacement in the content of information messages, insofar as technology was thematised in news considered as "interesting" or "priority", vying with or even replacing other types of news, including the political, financial, and social kind:

[I access] very diverse content on the Internet; I'm really keen above all on new technologies, computer science and all that and I tend to be fairly well informed. (C-S5)

I read what interests me, about IBM, technology ... I'm a computer specialist, so I read a lot about Internet businesses. (C-S4)

In the words of Marshall McLuhan, for these receivers, "the medium is the message" Marshall McLuhan (1996). Nonetheless, all the euphoric values were accompanied by an awareness that the positive effects of these new tools were limited.

Some members of the "activist" discussion group cautioned that the vast amount of data accumulated on the Internet had already surpassed the reading, connection, and reflection capacity of human reasoning:

[ ... ] there's so much important news that it's impossible to cover everything. In other words, it's not covered. (A-S1)

With the Internet, the way things are going there's so much variety that I believe it's going to swamp us. (A-S5)

The members of the "conservative" group were also concerned about the vast proportions of the Web, which implied that the "task of news making" ultimately fell to users-individually understood and enunciated with a generic and purposive "you".

In reality, I always browse through it selecting [ ... ] content that seems interesting to me (C-S5). Recently, I cleaned up my Twitter account removing all types of newspapers, foreign and national press, because my timeline was so saturated that ... it's that there comes a time when you don't keep abreast of the news. The complete opposite happens, you stop doing so because you're completely overwhelmed. [... ]. (C-S6)

This is precisely one of the premises of the transmedial paradigm (Scolari 2016): all the content is served and available in different places, media, and platforms, so that it is users who, with their individual and active scrutiny, gradually shape their own narrative through their discourse. It is like a network interwoven with the individual pathways of each user, who navigates through its vast infrastructure according to his or her individual choices.

\subsubsection{Displacements in the Digital Public Space: From Linearity to Navigation}

The daily routines of nearly all the subjects revolved around computers and mobile phones, devices seeking to displace the television screen or the magazine rack from the central position that it had occupied during the second half of the twentieth century, even in its spatial placement at home. Since the emergence of the paradigm of "remediation" (Bolter and Grusin 2011), we have known that technological change does not eliminate previous media, but absorbs them, modifying the core routines of new dynamics. This of course also affects the perception of the spaces that information technologies generate and which, as will be seen, has a direct impact on the type of spatial metaphor that emerges from it. These routines combined different media and platforms. In this connection, versus the "old media", hybrid and convergent platforms like social media have made users lose awareness of the borderline between the information, opinion, and entertainment genres. 
At home, we buy $A B C$, but I always like to browse the online versions of nearly all the newspapers in Spanish. I read El País a lot, I read El Mundo a lot, ABC, I also read La Razón; and foreign newspapers like The Guardian and The Washington Post, at a certain level of course ... . Above all, I like Twitter as an information channel: news that maybe appears on Twitter and which redirects me to the online version of the respective newspaper. (C-S1)

I consult everything on the Internet. I spend hours in front of my computer, therefore I hardly watch television. [ ... ] On the Internet I can find information on all sites, on specific news, series ... evidently I search on YouTube and in newspapers and on blogs and social media. (T-S1)

I try to obtain plural information from television newscasts, digital newspapers, some or other weekly

.... I try to vary them. And then also on social networks, from groups of friends, from collectives to which we belong, which perhaps send you specific information. (IDI-S4)

Consumer habits are generically transmedial: everything circulates, everything is to be found, hybridised, and combined in the new media, because this does not only derive from the offerings presented to the senses of users, but also it is they who, in the course of their navigation, jump from one thing to another.

The navigation metaphor describes a practice that goes way beyond the enlightened concept of reading: First and foremost, because the linear reading model of narrative is surpassed by "I choose" or "I want to view or know and look for it". Secondly, because it is the readers themselves who "write" with their navigation, in a gradually less implicit fashion, leaving a trail of their preferences, priorities, thematic agendas, and even their political leanings. "Navigators" do not necessarily produce the same object as journalists or opinion makers, but, with the record of their movements, simply and indirectly produce a highly valuable object for advertisers and corporations, who purchase those digital trails as if they were goods to design customised advertising and in the case of social media or search engines, even to display a series of related content, while discarding others, by means of algorithms. In light of the foregoing, the members of the discussion groups represented the digital public sphere not now as an open field for day-trippers, or as a "cold" (McLuhan 1996) or "transparent" medium (Han 2012), but as a sort of traffic labyrinth in which walls and screens created the illusion of freedom of movement:

I choose what I watch on the Internet. If I want to watch porn, I watch porn. If I want to watch series, I look for series. I choose, I can't stand what they put on television, that's what I'm getting at. But also, as he says, there's something behind it, I can tell that intrinsically that's the case. I've worked in advertising and I know, because we all try to fool each other. Intrinsically, we make them see that this is free. But no, everything's measured. Everything, psychologically everything's studied. I'm not saying it's not, but at least nowadays you've got more capacity to choose a bit what you want to watch, that's all. (T-S1)

\subsubsection{The Need for Organised Trips}

In view of this attitude of "exploration", the "old media", with television at the forefront, were perceived as suspect. This was first expressed was a unanimous wariness: the "old media" were accused of being the exclusive mouthpieces of the official discourse of the different powers: "On television, I'm practically interested in the 24-h newscast as a thermometer, to see, as it were, how the system's ruling party is faring. Then, of course, I access other sites" (WHE-S4).

In relation to the presence of both public and private media outlets on the Web, the former were seen as a nexus of continuity between old and new practices. 
The pre-existing press has moved to the Internet and, in reality, that's what we mostly consume. If those companies have more money it's because they are communication emporiums that have been built over many years; and [consequently], they'll also have more money for having a greater presence on the Internet. (PSW-S7)

The initially positive assessment of ICTs was nearly always followed by a moment of apprehension: the fear that the bad practices of the "old media" would prevail in the new ones by the inertia of the colonising effect, often in disguise: I see the media as transvestites. [Laughter] [ ... ] I transform myself, I disguise myself, I switch over to the Internet, I act on the Internet, as I previously acted in other spheres (WHE-S4).

Although when that happened, the subjects always referred to third parties who would passively condone that colonising effect, drawing an immovable line between themselves and the masses who did not make the most of the liberating possibilities of that technology which had been highly valued at first. The members of the "technophile" group expressed this idea clearly, employing the metaphor of the organised trip—bad practices—versus the individually planned trip—best practices:

[ ... ] They access the Internet but they are still participating, as it were, in a sort of guided trip, as if they were on an organised trip on the Internet. Not like what occurs now, when you buy your own ticket, you organise everything and you contact someone. For me, in contrast, most of the Internet's still like what happens with tour operators, that they are more or less guided and they are taught different things. (T-S2)

If you're aware that precisely media like El País and the rest of them are controlled by the same hand, you can at least resort to those others that don't have anything to do with that. And that's the Internet: it's a tool that's given us that freedom, which I don't believe is only feigned. (T-S5)

This reasoning highlights that the concept of navigation expressed in the discourses of the subjects heaps all the responsibility on individuals, demanding that they be discerning with the information that they consume, something that previously corresponded to professional journalists, while also imposing an individualist meaning on social reality. From this point of view, the constitutional principle enshrined in Article 20 d) of the 1978 Spanish Constitution (Boletín Oficial del Estado 1978)—in which "the right to freely communicate or receive accurate information by any means of dissemination whatsoever" is recognised and protected-would become a strictly personal, individual, and private issue, whereby it would be inviable for the state to guarantee such a right, without a journalistic profession with defined functions and the adequate conditions for ensuring their compliance.

\subsection{Purposive Assertions: Demands for Change in the Placement}

\subsubsection{A Place Inhabited by Multiple Voices and a Guide}

While professional roles and profiles have been reconsidered as a result of digitisation (see García de Madariaga 2014; Aguilar in Lamuedra-Graván 2012, pp. 175-89), the very habits of receivers, in permanent tension between suspicion and the individual assumption of the responsibility to maintain heathy information consumption habits, cast doubt not only on the agents providing PIS, but also the validity of the organisations as such themselves. Are they really necessary if individuals should organise "their own trips"?

As for the presence of receivers and their capacity of agency in this new context, the origins of these dynamics are to be found in a situation in which ordinary citizens gain prominence through the use of tools, such as SMS, the forerunner of participation in cybernetic conversations by means of hashtags created by the programmes themselves or the media per se. For the subjects, this system of "opening comments" was considered a priori as an interesting possibility, albeit not entirely convincing, in which they could either generate content through transmedial convergence or a "dialogue" - in a 
Bakhtinian sense of the word ${ }^{2}$ - even with the ability to call into question the discursive line circulating through the principal medium:

There were quite a few journalists who recognised that the comments made from below, on websites, or how they posted a tweet decrying and highlighting that a specific media outlet was concealing information [ ... ], was working really well, it was pounding away and it was involving a pure citizen control that, in fact, is now being constructed. (A-S3)

The fact that you can currently use a hashtag on a social networking site for any broadcast or that any programme has its hashtag on social media, [means that its] viewers can really criticise directly what they are watching on television. You become an active member or you're being seen on screen. [ ... ] you can participate. (T-S5)

The subjects' testimonies also point to individual participation, but as members of the abstract community of "the public":

I don't think that social networks as they are should be undervalued, because they are a very powerful tool. Many people are constantly posting comments and they indeed have the same level of importance than the media; at a business level, at an advertising level ... I believe they are being taken into account more and more, it's something that's important for the future of both communication and the system in general. [ ... ] For instance, the platform Change.org. (T-S5)

In this respect, however, the role of social media users would in no way be that of prosumers, but that of spokespeople, who, with their movements of adhesion and their sharing, amplify or enhance pre-existing messages in an immense echo chamber by making them go viral. Yet, although they perceived the effects of these dynamics as being limited, focusing on the finite attention span of those "travelling" to some or other place, for the subjects, it was a positive aspect:

When certain issues go uncontrollably viral, they might become the hashtag of the day. Everyone starts to comment on them and something happens. [ . . ] It's a moment when there's a huge square, a huge agora full of people demanding, for example, that we don't want any more corruption. And the next day, even though everyone decides to go home and tweet about a dress, even that has had a meaning, even though it doesn't seem so. And that manipulates public opinion, which will probably make it more agile against the doctrines of shock. (A-S1)

This view was also held in the other discussion groups, in which the subjects talked about mobilisation platforms, signature campaigns, and strategies for disseminating public affairs, beyond the journalistic character or not of the content in question:

I think that they [ICTs] could have a very interesting mission, which is to make civil society an intermediary and the volume of data produced in what's now called open data; [... ] perhaps the digital media are heading somewhat in that direction: attempting to reflect a summary or synthesis of many news stories that are now produced in relation to all the available data, more than anything because at an individual level it's difficult for you to manage them. (SP-S1)

Dialogue as the convergence of discourses, stories and narratives in the same textual space, occasionally generating relationships that are sometimes stabilising and sometimes destabilising (Bakhtin 1986, pp. 67-68). Understanding media and social dialogue in these terms (Sánchez-Mesa 2015) allows for elaborating a comprehensive vision of culture as a negotiation of meaning open, of course, to social change. 
In this connection, the subjects yet again voiced their concern about the figure of the "guide", which could be a response to the responsibility that individuals shoulder in organising already explored information itineraries. The image of the professional with higher education and training still occupied a prominent place in their shared imaginary:

It seems to me that journalists are also essential, that is, professional journalists. [There're] many information sources, many different kinds of information sources and in that respect I think they [journalists] also play that role. [... ] And to create [... ] the necessary conditions so as to allow them to work independently. (A-S3)

I agree there should be scientific journalism that promotes democratic values and that not everything goes. I don't want that kind of freedom of expression because it doesn't promote values that foster citizenship. I want detailed, proven scientific information, I don't want the opinion of anyone. (T-S2)

[ ... ] after all, journalism's taught at university and it's a profession. Let's leave the professionals to work without constraints and let's protect them with an umbrella so that they aren't coerced by the incumbent government or company or power ... and that they should be held accountable to the citizenry. (PSW-S5)

Therefore, the subjects' most consensual demands, namely, fostering the participation of the public and that PIS should act as a guide, were those aimed at enhancing aspects already forming part of the system.

\subsubsection{A Place Open to Community Participation: The Square}

Another front opened by ICTs was the creation of alternative media. This reasoning emerged in the "activist" discussion group, in which distrust towards the private interests of the major media companies and the public sector's neglect of its duties suggested the need for socially organising groups or movements that act as a counterweight to the illegitimate occupation of the media space of the public sphere by those yet again threatening to colonise the social space in dispute:

But the media have indeed known how to channel that in some way, right? For example, the fact that $E l$ País broadcast in streaming the protests, the taking of Congress and all that, I believe that's indeed a way of channelling the fact that people are angry and want to change things, right?. (T-S5)

In Spain, during the 2010s, there emerged media outlets with a certain amount of relevance and presence, such as LaMarea, Eldiario.es, Infolibre, and El Salto, among others, organised as journalism cooperatives and with a strong commitment to the profession, but whose main problem was their financial survival in the face of competition from the established media groups. The members of the "activist" group approved of these initiatives, albeit fully aware of the difficulties that they faced:

But you see the audience that eldiario.es has on the Internet. [ ... ] The print versions are ridiculous in comparison with the audience that an online newspaper can have. They can't be quantified in the same way, they aren't comparable, but what I want to say is that the paradigm's shifting. And the question is what you say [... ]: How can that be financially viable? [ ... ] It'll be an important debate. (A-S5; in response to a previous statement made by A-S2)

The members of the "activist" group also broached the subject of empowering the citizenry, thus allowing non-professionals to create their own media. The diminishing cost of technological devices and the possibility of disseminating content on the Internet were the main reasons why this horizon appeared as a desirable utopia: 
There're also local collectives that club together to create a newspaper and bit by bit manage to get along. (A-S2)

[ ... ] some time ago, with some friends, a movement and what have you, we tried to start up a sort of news programme on the Internet. And everyone felt really empowered, because it's an element-how can I say?-a real totem of our society. A newscast is a newscast, right? And you set it up ... for them it's really difficult .... Public resources should be used, [ ... ] public television should help people to acquire resources and skills so as to be able to speak. It's one of the main roles of public television. While providing information, it's important to facilitate participation. (A-S3)

In the "activist" discussion group, there was also talk about revitalising "community media", relaunched thanks to the new technical context and dissemination of the limits between the public - accused of having abandoned its public service remit - and the private sector-for, after all, community media are financed by private citizens who become prosumers as a reaction against the system:

But we also have to make the other media, community media which we have to finance ourselves, accountable. I don't want a community media outlet, which us locals are creating, to receive a subsidy from the council, because as soon as it receives a subsidy from the local council, I no longer trust that it'll defend me. That doesn't mean to say, of course, that there can't be another media outlet financed by the local council. (A-S5)

Ultimately, the subjects imagined the public place as a space for collective discussion, a sort of public square, in which it was urgent to recuperate in direct competition with those public bodies that no longer built trust or provided a PIS, but with which it still had to coexist. In the opinion of another member of the "activist" group, an alternative would be to create a mixed public-private system, in which "prosumers" undertook all the tasks, meaning that they would become non-professional producers subject to an extra-governmental control system:

They [the media] must be public, but, as we were commenting, communal, that it should be the citizens themselves who create those media. And those would be public or community, whatever you want to call them, but not under governmental control—whatever the government, even the local kind. [ ... ] They should belong to all, should be made by all and for all, available to the people, without a politician controlling them. [... ] And that possibly interests you a lot more than being informed about what's happened in that neighbourhood or that village, and that you're being shown this by a private company, which obviously has economic interests, or a politician with political interests. In that way, yes: a lot of public variety, but they should provide that type of public service: made by all for all. (A-S5)

In this regard, it is obvious that the subjects were not familiar with already existing concepts and tools, like the "right of access" to public media (see Transitional Provision No. 6 of the Law 17/2006, of 5 June, on state owned radio and television; cfr. "Reglamento de Derecho de acceso de RTVE" [Regulations for the right of access to RTVE] $]^{3}$ ), by means of calling public tenders, which although their purpose is to channel these types of demands, have not yet been fully developed.

\subsubsection{The Internet as a Square for a Virtual and Solidary Community}

In the "technophile" discussion group, at a certain moment in the conversation, the members addressed that place, making it possible to explore a series of potential options between the continuity 
of the "old media" and the emergence of alternatives to "bad practices" for the sake of reoccupying the public place. In analytical terms of historical materialism, they reflected on the material "infrastructure", or productive forces, possessed by a society, which underpins the political and ideological superstructure. Some of the members of the "technophile" group recounted how a new paradigm had emerged from free software, with which they were familiar and used in their personal and work routines with different computer devices:

At home, I work with free software, with Open Office. [ ... ] I share my knowledge with whoever wants to share with me and they share with me $[\ldots]$. Then, that freedom [ ... ] I now have it at this moment, in my hands [ ... ]. So, I believe that open source code and sharing things is the only way that mankind can evolve and progress more swiftly. (T-S1)

That statement combines several topics. Firstly, this subject explained that he used the office suite developed by Openoffice.org, a platform belonging to the Apache Software Foundation on which users can both download the alternative office apps to the Microsoft or Apple Office suites, and access the programming code itself of those apps to modify or improve it. This code, which has been generated publicly and freely, is still the same, insofar as it has been elaborated on the basis of joint deliberation in a virtual and common space. Thus, this member of the "technophile" group benefitted from a software that he had been able to download legally and free of charge, circumventing the duopoly of Microsoft and Apple.

The euphoric values of progress and freedom, towards a utopia, a radical change in mentality, and in the social organisation of labour, appeared yet again at this point:

That was the original idea that floated on the Internet like a free community, as I said, of the right to information. [... ] I think that it's an intellectual evolution, in which the good-which could be software- -becomes something else. (T-S2)

However, "free" does not mean "free of charge". If no one earned a wage for contributing to its construction and at the same time, no one paid to access the finished product, which is readily available and public, the concept of good, plus that of authorship, would be completely eliminated:

But that paradigm clashes with the system. Because that paradigm is a paradigm of collective intelligence, in which the product isn't a good that has a market value. And, for instance, you'll clash with the system, because it wants to convert absolutely everything into goods. The air is populated here? Well, buy a chalet on the outskirts of Madrid. (T-S2)

\section{Discussion}

The perceptions and demands that we have described above can be represented as a catalogue of possible spatial metaphors: an encyclopaedia, a network, a sort of place inhabited by multiple voices, a guide, and a place open to community participation. All these metaphors can be classified in two spatial extremes or macro-metaphors: (1) the rivalry between a complex system of individual and one-way traffic, resembling a labyrinth, and (2) the metaphor of the public square that should be inhabited and, in the extreme, occupied with the body and voice. The discourses underpinning both spatial metaphors share the image of a great encyclopaedia, although with different ways of relating to it.

On the one hand, the first placement tends to be characterised by the euphoria of those inhabiting it and their individualism. We have detected the belief of users that they can and know how to circulate through it as if it were a traffic labyrinth. This is a spatial conception that is constructed in segments, through which it is possible to circulate by means of commodified transactions based on needs understood as particular. Thus, this would give rise to a disruptive or centrifugal meaning, which emerges in individual figures in the discourse, located in a fragmentary and hierarchical space in which subjects are responsible for their own displacement, depending on their needs, towards achieving their objective, inasmuch as they can purchase the good. This action is conceived as an 
individual journey on which users, with or without a guide, are capable of exercising their power of choice in a sort of unfathomable network, but in which they know how to move with a certain amount of freedom. They feel superior to others and empowered to use the media system-visualised either as a great encyclopaedia or as a network-freely.

The other discursive extreme recognises and is distrustful of the capacity of the agency of individuals in the aforementioned labyrinth and surpasses economic value as the basis of life. This then gives rise to a meaning with a conjunctive and centripetal propensity and a collective conception of subjects, who would ideally be located in an open, freely accessible place where they can circulate at will-a utopian or euphoric idea. The conception advocates for the recuperation of the public space, governed by an "authentic" PIS as a benchmark for these new virtual spaces in terms of a collective or inclusive dimension. In relation to the foregoing, it is possible to perceive two demands that are being made of the media system in line with the idea of revitalising the public place metaphor: the contribution of the media to structuring local communities and the Web as a global agora for sharing knowledge.

\section{Conclusions: Towards a Referent of PIS in the Digital Public Space}

In this rivalry between the two spatial metaphors (the one-way traffic labyrinth/network and the uninhabited or occupied public square), it can be seen how the remit of public service broadcasting is sometimes evoked. We would like to dwell on this issue because of its potential for vitalising the spatial metaphor of the public square or the dialogic agora. In the one-way traffic labyrinth, only a central position allows for gaining an overview by ascending. As a result, the model of this spatial metaphor contains a narrative of individual ascent. Only from the summit is it possible to occupy an autonomous and rational position, although of course through control, surveillance, guiding, and ultimately, the exercise of power. On the other hand, the spatial metaphor of the public square involves an intersubjective narrative. Notwithstanding the fact that the representation of this metaphor does not cease to correspond to a "utopian moment", the image of the public square does not imply any reductionism. On the one hand, it is still a metaphor and on the other, the models that we have described take into consideration that such a broad space of collective interaction requires different narrative itineraries, ranging from the figure of the guide to its occupation when there is a disconnection between subjects and a disorientation resulting from information overload (perhaps as an episode of agoraphobia in a saturated space). In this dispute between two opposing models (one guided by the narrative of the individual good and the other governed by that of the common good), there is the need for a benchmark and a tool for countering the imbalances, which would be PIS.

With respect to the discourses relating to PIS, this appeared more clearly as a guide when first addressed in those groups and at those moments of the conversation when there were suspicions about the purposes that the infrastructure served. Nonetheless, there was also a minority demand for the possibility of reactivating the second, namely, the public place.

The stances described above also share a number of "certainties": (1) the need to resort to guides like journalists or PIS, a notion that coexists with (2) a great mistrust of the powers that be and the control of the media, including the public ones.

It is not enough to expand television by broadcasting the same content in new virtual spaces. Instead, a common space, with the minimum conditions of dialogical interaction guaranteed by PIS (Mills 2018), should be ensured by means of the architecture of the digital system itself (resorting to open source code and the possibilities of free software), rather than leaving that social space in the hands of private agents, like Google and Facebook, which is what has occurred until now.

In sum, to cope with the "moment of uncertainty" in which we currently find ourselves at the beginning of the second decade of the twenty-first century, it would be interesting to examine the experiences of previous years. Without a shadow of doubt, the challenges facing society in 2020, including above all the post-COVID-19 crisis which seems evitable, differ from those that triggered the global financial crisis in 2008. However, the accumulated experience seems to indicate that, in the face 
of the technology and information boom, from which we may either benefit or lose out, this has a direct impact on the social model that is constructed between the spatial metaphors of polarised, segmented groups who tend to heed only their own voices and messages, and that of the public square in which devices allow for a debate that bolsters the position of subjects by means of the "disposition" of plurality. At this crossroads, the public media, whether they be state-owned technological networks or guarantors of the dialogic and polyphonic plurality of the products circulating through that same infrastructure, must establish their leadership in the construction of a truly common space. Certainly, the type of metaphor that consolidates its position as the hegemonic representation will result from a challenge that has yet to be met—-both the model of the "square", which we have described here as a space of interaction, and the period during which that same space may vary according to the future movements and narratives of agents, devices, and technologies in the age of boundless digital mediation.

Author Contributions: Conceptualization, M.A.B.-L. and M.L.G.; Investigation, M.A.B.-L. and M.L.G.; Project administration, M.L.G.; Resources, M.A.B.-L. and M.L.G.; Supervision, M.L.G.; Writing-original draft, M.A.B.-L. and M.L.G.; Writing-review \& editing, M.A.B.-L. and M.L.G. All authors have read and agreed to the published version of the manuscript.

Funding: This study was performed in the framework of the project entitled, "Dinámicas de Relación ante el Cambio Social: Contextos, Contenidos, Productores, Público y Produsuarios en las Noticias de TVE e YLE" (Plan Estatal 2013-2016 Retos, MINECO and European Union ERDF funding, ref. CSO2013-45470-R), led by María Lamuedra Graván and Manuel Ángel Vázquez Medel.

Conflicts of Interest: The authors declare no conflict of interest.

\section{References}

Adams, Paul C., and André Jansson. 2012. Communication Geography: A Bridge Between Disciplines. Communication 22: 299-318. [CrossRef]

AIMC. 2012. La Televisión: Tradicional vs. Online. Available online: www.aimc.es/La-Television-Tradicionalvs, 1050.html (accessed on 8 October 2020).

Alonso, Elisa, Manuel A. Broullón-Lozano, and María Lamuedra-Graván. 2016. Análisis empírico de las dinámicas de remediación entre televisión e internet en España: Discursos de receptores. Revista Latina de Comunicación Social 71: 160-96.

Álvarez-Peralta, Miguel. 2014. La crisis estructural del periodismo en España. El Viejo topo 322: 58-64. Available online: https://www.academia.edu/17237432/La_crisis_estructural_del_periodismo_en_Espa\%C3\% B1a (accessed on 8 October 2020).

Bakhtin, Mikhail. 1986. Problemas de la Poética de Dostoievski. México: Fondo de Cultura Económica.

Boletín Oficial del Estado. 1978. The Spanish Constitution. Madrid: Cortes Generales, December 29.

Bolter, David Jay, and Robert Grusin. 2011. Inmediatez, hipermediación, remediación. CIC Cuadernos de Información y Comunicación 16: 29-57. [CrossRef]

Bordwell, David. 2009. Now Leaving from Platform 1. Available online: http://www.davidbordwell.net/blog/ 2009/08/19/now-leaving-from-platform-1/ (accessed on 8 October 2020).

Bustamante, Enrique. 2008. Public Service in Digital Age: Oportunities and treats in a diverse Europe. In Communication and Cultural Policies in Europe. Edited by Isabel Fernández Alonso and Miquel de Moraga. Barcelona: Generalitat de Catalunya-Catedra Unesco de Comunicació.

Callejo-Gallego, J. 2002. Observación, entrevista y grupo de discusión: El silencio de tres prácticas de investigación. Revista Española de Salud Pública 76: 409-22. [CrossRef]

Cebrián, Mariano. 2004. Modelos de Televisión: Generalista, Temática y Convergente con Internet. Barcelona: Paidós.

Conde, F. 2009. Análisis Sociológico del Sistema de Discursos. Madrid: Centro de Investigaciones Sociológicas.

Eco, Umberto. 2013. Apocalípticos e Integrados. Barcelona: Lumen.

Elwood, Sarah, and Agnieszka Leszczynski. 2013. New spatial media, new knowledge politics. Transactions of the Institute of British Geographers 38: 544-59. [CrossRef] 
European Commission-Directorate General Communication. 2016. Standard Eurobarometer 86. Report: Media Use in the European Union. Brussels: European Union.

European Commission-Directorate General Communication. 2018. A Multidimensional Approach to Disinformation. Brussels: European Union.

García de Madariaga, José M. 2014. New mediations in the digital age: An analysis of global communication through media professionals. In Global Communication. New Agendas in Global Communication and Media Studie. Edited by Karin Wilkins, Joe Straubhaar and Shanti Kumar. London: Routledge.

García de Madariaga, José M., Manuel A. Broullón-Lozano, and María Lamuedra-Graván. 2016. La televisión pública ante los desafíos de la convergencia digital: Percepciones de la audiencia y de profesionales de TVE. Mediatika 15: 79-99.

Gauthier, Philippe. 2018. Inmersión, redes sociales y narrativas transmedia: La modalidad de recepción inclusive. Comunicación y Medios 37: 11-23.

Gavaldà Roca, Josep, Miquel Francés Domènec, and Germán Llorca Abad. 2016. La política de la comunicación de la crisis. In La televisión de la Crisis ante el Abismo Digital. Edited by Miquel Francés, Josep Gavaldà Roca, Germán Llorca Abad and Àlvar Peris Planes. Barcelona: Gedisa, pp. 81-121.

Han, Byung-Chul. 2012. La Sociedad del Cansancio. Barcelona: Herder.

Imbert, Gerard. 2008. El Transformismo Televisivo: Postelevisión e Imaginarios Sociales. Madrid: Cátedra.

Jenkins, Henri. 2008. Convergence Culture: La Cultura de la Convergencia de los Medios de Comunicación. Barcelona: Paidós.

Lamuedra, María, Concha Mateos Martín, and Manuel A. Broullón-Lozano. 2018. Normative and Audience Discourses on Public Service Journalism at a "Critical Juncture": The Case of TVE in Spain. Journalism Studies 20: 1528-154. [CrossRef]

Lamuedra Graván, María, Concha Mateos, and Manuel A. Broullón-Lozano. 2020. The role of public service journalism and television in fostering public voice and the capacity to consent: An analysis of Spanish viewers' discourses. Journalism 21. [CrossRef]

Lamuedra-Graván, María. 2012. El Futuro de la Televisión Pública. La Necesaria Alianza con la Ciudadanía. Madrid: Editorial Popular.

Lozano, Jorge, Peña-Marín Cristina, and Abril Gonzalo. 1982. Análisis del Discurso. Hacia una Semiótica de la Interacción Textual. Madrid: Cátedra.

McLuhan, Marshall. 1996. Comprender los Medios. Las Extensiones del ser Humano. Barcelona: Paidós.

Media Intelligence Service. 2017. Public Service Media. Contribution to Society. Geneva: European Broadcasting Union.

Media Intelligence Service. 2018. Trust in Media 2018. Geneva: European Broadcasting Union.

Mills, Tom. 2018. We Need a Nationalised Alternative to Facebook—and the BBC Could Provide the Answer. The Independent. Available online: https://www.independent.co.uk/voices/facebook-cambridge-analyticabbc-nationalised-alternative-a8269066.html (accessed on 8 October 2020).

Pérez Tornero, José Manuel. 2020. La Gran Mediaticación I. El Tsunami que Expropia Nuestras Vidas. Del Confinamiento Digital a la Sociedad de la Distancia. Barcelona: UOC.

Rodríguez-Amat, Joan Ramon, and Cornelia Brantner. 2016. Space and place matters: A tool for the analysis of geolocated and mapped protests. New Media and Society 18: 1027-46. [CrossRef]

Salmon, Christian. 2008. Storytelling. La Máquina de Crear Historias y Formatear las Mentes. Barcelona: Península. Salmon, Christian. 2011. La estrategia de Sherezade. Apostillas a Storytelling. Barcelona: Península.

Sánchez-Mesa, Domingo. 2015. Los estudios sobre cibercultura y los new media. Caracteres. Estudios Culturales y Críticos de la Esfera Digital 4: 79-99.

Sánchez-Mesa, Domingo, Espen Aarseth, Robert Pratten, and Carlos A. Scolari. 2016. Transmedia (¿storytelling?): Una revisión crítica y polifónica. Artnodes 18: 8-19.

Schlesinger, Philip. 2000. The nation and communicative space. In Media Power, Professionals and Policies. Edited by Howard Tumber. London: Routledge, pp. 99-115.

Scolari, Carlos Alberto. 2016. Narrativas Transmedia: Cuando Todos los Medios Cuentan. Barcelona: Deusto. 
Vázquez Medel, Manuel Ángel. 2003. Teoría del Emplazamiento: Aplicaciones e Implicaciones. Sevilla: Alfar. Vázquez Medel, Manuel Ángel. 2017. Neuroinformación: Hacia un cambio epistémico en el análisis de las manipulaciones informativas. IC. Revista Científica de Información y Comunicación 14: 55-74.

Publisher's Note: MDPI stays neutral with regard to jurisdictional claims in published maps and institutional affiliations.

(C) 2020 by the authors. Licensee MDPI, Basel, Switzerland. This article is an open access article distributed under the terms and conditions of the Creative Commons Attribution (CC BY) license (http://creativecommons.org/licenses/by/4.0/). 